\title{
KHAWARIJ DAN ISU RADIKALISME
}

\author{
H. LALU MUHAMAD FAZLURRAHMAN \\ UIN MATARAM \\ fazlurrahmanuin@gmail.com
}

\begin{abstract}
Radicalism is the opposite of the moderation values that Islam has brought since 1400 years ago which attracts people to study and deepen it but many people argue that the value of moderation in Islam is not complete and pure, as evidenced by the thoughts of radicalism among muslims which in its history began in an organized manner since the events of the tahkim or arbitration between Ali and Muawiyah with the emergence of the khawarij sect then continues untill now with the justification of the existing radical or extremist groups using their extreme thoughts in every action. This research tries to analyze that opinion with historical approaches and holy texts both al-qur'an and hadith through a variety of interpretations of experts so as to get a complete and comprehensive understanding avoid from the bias of mazhab and fanaticism.
\end{abstract}

Keywords : moderation, khawarij, extremist, interpretation.

\section{Abstrak}

Radikalisme adalah antitesis dari nilai-nilai moderasi yang dibawa Islam sejak 1400 tahun yang lalu dan menarik orang untuk mengkaji dan mendalaminya, tapi banyak kalangan berpendapat nilai moderasi dalam Islam tidak utuh dan murni, dibuktikan dengan pikiran-pikiran radikalisme dalam umat islam sendiri yang dalam sejarahnya dimulai secara terorganisir sejak peristiwa tahkim atau arbitrase antara kelompok Ali dan Muawiyah dengan munculnya sekte khawarij kemudian berlanjut sampai saat sekarang dengan adanya justifikasi dari kelompok-kelompok garis keras yang ada saat ini menggunakan pikiran-pikiran ekstrem mereka (khawarij) dalam setiap aksi-aksinya. Penelitian ini mencoba menganalisa pendapat tersebut dengan pendekatan sejarah dan teks-teks suci baik al-qur'an maupun hadits melalui variasi interpretasi para ahli sehingga mendapat pemahaman yang utuh dan komprehensif terhindar dari bias-bias mazhab dan fanatisme. 
Kata kunci: moderasi, khawarij, ekstremis, interpretasi

\section{A. Pendahuluan}

Pada dasarnya Islam agama yang sesuai dengan zaman dan tempat (shalihun likulli zamanin wa makan), atau dalam bahasa lain islam agama kemanusiaan, agama perdamaian dan agama yang menjunjung tinggi nirkekerasan, tapi akhir-akhir ini banyak pihak menuding islam dengan isu-isu radikalisme, seolah-olah bahwa konflik-konflik yang terjadi yang memakan korban begitu besar belakangan ini lahir dari ajaran-ajaran islam itu sendiri. Benarkah demikian, untuk mendapat jawaban yang utuh dan komperehensif, maka perlu dilihat dari dua sisi yaitu radikalisme dan islam itu sendiri, yang pertama pengertian radikal, kata radikal berasal dari bahasa latin radix yang berarti akar pada perkembangannya sebagai ungkapan untuk gerakan, individu atau kelompok yang memperjuangkan perubahan sosial atau sistem politik secara mendasar dan menyeluruh.

Istilah "radikal" muncul di panggung politik kira-kira abad ke-18 di Eropa dan ke-19 di Amerika Serikat, dalam perkembangannya pengertian radikal mengalami banyak pergeseran menjadi paham yang melihat segala sesuatu sebagai prinsip,akar,esensi sehingga jika diibaratkan dengan pohon tidak mengenal ranting, daun, atau yang lainnya semua dilihat sebagai akar dan karena pandangan itu pemahaman ini cenderung mengambil "jalan akhir" dalam tanda kutip yaitu kekerasan dan kemudian menjadi pema- 
haman yang tidak menerima selain jalan kekerasan dalam melakukan perubahan-perubahan sosial atau politik.

Sementara islam adalah agama yang diturunkan kepada Nabi Muhammad SAW, agama yang menurut banyak kalangan simpel, mudah dipahami dan dilaksanakan yang kemudian menjadi karakternya sekaligus daya tarik tersendiri dari waktu ke waktu, simpel dan mudah ini tercermin dari ajaran-ajarannya, baik yang sifatnya prinsip atau sekunder. Sebagai contoh, dalam hal pelaksanaan shalat yang bersifat prinsipil, perintah awal sholat dengan berdiri tetapi jika tidak bisa terlaksana dengan berdiri, maka boleh dilaksanakan dengan duduk, jika tidak bisa duduk, maka bisa berbaring.

Contoh lain, puasa di bulan ramadhan juga menjadi salah satu rukun atau prinsip-prinsip islam, jika tidak bisa dilaksanakan karena ada uzur atau halangan, maka boleh ditinggalkan dan diganti dengan qadha' atau dilaksanakan pada waktu yang lain. Demikian halnya dalam ibadah-ibadah yang lain kemudahankemudahan selalu diberikan dan semua itu membuktikan karakter islam yang mudah dan simpel.

\section{B. Dasar Argumentasi}

Dalam berbagai ayat al-qur'an dan hadits banyak sekali perintah-perintah dan sabda rasulullah yang menunjukkan kecenderungan-kecenderungan dan karakter-karakter moderat ini, yang memudahkan tidak mempersulit, yang inklusif tidak ek- 
sklusif, didalam sebuah ayat Al-Qur'an yang artinya Allah berfirman : "dan demikian (pula) kami telah menjadikan kamu (umat islam), (pula) kami telah menjadikan kamu (umat islam), umat yang adil (moderat), agar kamu menjadi saksi atas (perbuatan) manusia dan agar Rasul (Muhammad) menjadi saksi atas (perbuatan) kamu" . Di sebuah hadis di jelaskan : "dari jabir bin samurah berkata, aku telah shalat bersama Nabi SAW berkali-kali, dan (aku dapati) shalatnya dalam pertengahan, khutbahnya juga pertengahan"'.

Didalam hadits lain dijelaskan : "mudahkan dan jangan mempersulit, berikan kabar gembira dan jangan membuat manusia lari³. Dalil-dalil ini menunjukkan dengan terang bahwa karakter islam adalah moderat dan mudah tidak mempersulit. Nilai-nilai ini juga menjadi semangat para ulama dalam menyimpulkan dan mengambil berbagai hukum dengan metode qiyas (analogi) atau metode-metode yang lain, sehingga kesimpulan hukum yang dihasilkan berdasar nilai-nilai moderasi dan inklusifisme, bukan hanya hukum atau aturan-aturan dalam ibadah mahdhah, juga terkait dengan sosial, politik bahkan ekonomi.

\section{Sejarah Radikalisme Dalam Ke-khalifahan}

${ }^{1}$ Qs. Al-Baqarah : 143

${ }^{2}$ Al-Imam Muslim, Shahih Muslim (Kairo, Dar Al-Thayyibah, 2006) No. 1492

${ }^{3}$ Al-Imam Al-Bukhari, Shahih Al-Bukhari (Beirut, Dar Ibnu Katsir, 2002) No. 69 
Ketika terjadi suksesi kekuasaan dari Usman ke Ali terjadi banyak intrik-intrik dan ketidakstabilan politik, dikarenakan suksesi pemerintahan dari Usman ke Ali tidak normal, yang disebabkan oleh terbunuhnya Usman yang berawal dari ketidakpuasan sebagian rakyatnya karena klaim-klaim nepotisme yang telah di lakukan Usman dalam enam tahun kedua masa kekuasaannya yang puncaknya ketika rakyat mesir tidak puas dengan gubernur mesir ketika itu Abdullah bin Abi Sarh, yang kemudian mengakibatkan terbunuhnya Usman di rumahnya dengan cara disembelih.

Setelah terbunuhnya Usman, mayoritas masyarakat ketika itu menginginkan Ali sebagai suksesornya, pada akhirnya Ali terpilih sebagai khalifah yang ketiga selama kurang lebih lima tahun, selama lima tahun masa kekuasaan Ali dipenuhi dengan berbagai ketidakstabilan dan goncangan politik, disebabkan sebagian rakyatnya menuntut dilakukannya investigasi terhadap pembunuh Sayyidina Usman, akan tetapi Sayyidina Ali yang ketika itu menjadi suksesor Sayyidina Usman tidak mau melakukan investigasi dengan berbagai pertimbangan salah satunya menurut beliau, jika dilakukan investigasi saat itu juga akan menyebabkan ketidakstabilan dan koflik besar antar masyarakat, apalagi menurut beliau kondisinya belum normal untuk melakukan investigasi, jika dipaksakan dalam pandangan beliau mudharat dan kerugiannya jauh akan lebih besar, oleh karena itu permintaan rakyat termasuk Gubernur Syam, Muawiyah ditolak oleh Sayyidina Ali. Hal ini kemudian yang 
menyebabkan terjadinya perang shiffin ${ }^{4}$. Sebelumnya terjadi Perang Jamal adalah perang yang terjadi pada tahun 656 Masehi antara Sayyidina Ali dan Saidah Aisyah dengan motif yang sama, sementara perang shiffin pada tahun 657 Masehi antara kubu Sayyidina Ali dan Sayyidina Muawiyah.

Dalam perang shiffin yang berkecamuk itu, yang menurut sejarawan telah membunuh puluhan ribuan orang, dari kubu Sayyidina Ali terbunuh 35.000 pasukan, dan dari kubu Muawiyah sekitar 45.000 orang, lebih lanjut dijelaskan sejarawan bahwa pada mulanya kubu Sayyidina Ali sudah menguasai medan dan hampir akan memenangkan pertempuran, akan tetapi dari kubu Muawiyah atas usulan Amr bin Ash mungusulkan agar pasukan mengangkat mushaf al-Qur'an dengan ujung tombak sebagai tanda perdamaian.

Dalam sejarahnya Sayyidina Ali enggan menerima tawaran damai dari kubu Muawiyah, tetapi karena kuatnya desakan dari pengikutnya, akhirnya beliau menerima dan mau mengadakan perundingan yang dikenal dengan istilah tahkim atau arbitrases. Dalam arbitrasi itu, kubu Ali diwakili oleh Abu Musa al Asy'ari sebagai juru runding, sementara Amr bin Ash sebagai juru runding dari kubu Muawiyah. Tidak semua pengikut Ali satu suara dengan arbitrasi ini. Kelompok yang tidak setuju yang kemudian memisahkan diri

4. William Montogomery Waat, The Formative Period of Islamic Thought, (Edinburgh: Edinburgh University Press, 1973), hal.12;Masudul Hasan, History of Islam, (India: Adam Publishers and Distributors, 1995), hal. 129-130.

${ }^{5}$ William Montogomery Waat, The Formative Period of Islamic Thought, (Edinburgh: Edinburgh University Press, 1973), hal.13. 
dari kelompok Ali ini selanjutnya disebut kelompok khawarij ${ }^{6}$, yang secara etimologi artinya keluar.

Dalam perkembangannya kelompok khawarij yang lahir dari peristiwa politik dengan jargonnya tidak ada hukum selain hukum Allah kemudian menjadi mazhab atau aliran teologis yang banyak diikuti oleh kaum muslimin ketika itu. Konsekuensi dari keyakinan mereka tersebut, mereka menghukumi banyak sahabat sebagai kafir, karena mereka meyakini dan mengikuti Sayyidina Ali dalam menerima tahkim atau arbitrasi, yang sesungguhnya dalam pandangan mereka menerima tahkim dengan Muawiyah sama saja dengan melawan hukum Allah, karena apa yang dilakukan oleh Muawiyah adalah bagian dari bughat atau memberontak, dan tidak ada hukum bagi yang memberontak selain nyawa. Khawarij sebagai aliran atau mazhab teologis, menurut para ulama sudah diisyaratkan rasulullah dalam haditsnya, yaitu dalam sebuah hadits yang diriwayatkan oleh Imam Al-Bukhari dalam shahihnya :

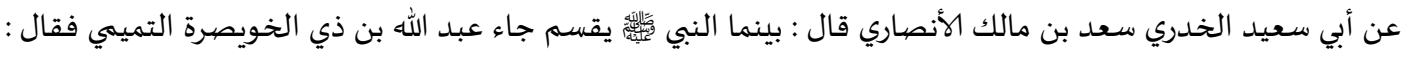
اعدل يا رسول الله فقال : ويلك من يعدل اذا لم أعدل ؟ قال عمر بن الخطاب : دعني أضرب عنقه قال : دعه فان له أصحابا يحقر أحدكم صلاته مع صلاته وصيامه مع صيامه يمرقون من الدين كما يمرق السهم من الرمية.

Artinya : "Dari Abu Sa'id Al-Khudri sa'd bin malik al-anshari, dia berkata ; "Ketika kami sedang bersama Rasulullah SAW yang sedang membagi-bagikan pembagian (harta rampasan), datanglah Dzul Khuwaishirah, seorang laki-laki dari Bani Tamim, lalu berkata hal. 132-133

${ }^{6}$ Masudul Hasan, History of Islam, (India: Adam Publishers and Distributors, 1995) 
; "Wahai Rasulullah, engkau harus berlaku adil". Maka beliau berkata : "Celaka kamu ! siapa yang bisa berbuat adil kalau aku saja tidak bisa berbuat adil. Sungguh kamu telah mengalami keburukan dan kerugian jika aku tidak berbuat adil". Kemudian Umar berkata ; "Wahai Rasulullah, izinkan aku untuk memenggal batang lehernya ! beliau berkata ; "Biarkanlah dia. Karena dia nanti akan memiliki teman-teman yang salah seorang dari kalian memandang remeh shalatnya dibanding shalat mereka, puasanya dibanding puasa mereka. Mereka membaca al-Qur'an namun tidak sampai ke tenggorokan mereka. Mereka keluar dari agama seperti melesatnya anak panah dari target (hewan buruan)" 7 .

Menurut ulama hadits ini adalah isyarat dari rasulullah akan munculnya kaum khawarij, karena jika khawarij atau khuruj dimaknai dengan pengingkaran akan pemimpin yang adil seperti yang dilakukan oleh Dzul Khuwaishirah dengan ciri-cirinya maka sesungguhnya benih pemikiran khawarij sudah ada semenjak keberadaan Rasulullah saw, dan terbukti Dzul Khuwaishirah bergabung dalam kelompok Khawarij yang memberontak Sayyidina Ali bin Abi Thalib.

\section{Interpretasi Al-Qur'an}

Selain dari motif politik, motif munculnya kelompok ini juga disebabkan kesalahan mereka dalam memahami atau menginterpretasi makna ayat dan salah satu indikasi kesalahannya adalah tidak ada satupun sahabat rasulullah yang bergabung dengan ke-

${ }^{7}$ Al-Imam Al-Bukhari, Shahih Al-Bukhari (Beirut, Dar Ibnu Katsir, 2002) No.3445

8) H. Fazlurrahman
Khawarij dan Isu Radikalisme... 
lompok ini, karena faktor kejahilan tersebut selanjutnya melahirkan fanatisme kelompok dalam mempertahankan pendapat dan keyakinan mereka pada akhirnya berujung kepada tragedi terbunuhnya Sayyidina Ali bin Abi Thalib pada tahun 661 Masehi. Jika membuka sejarah kelam kelompok ini terdapat ayat al-qur'an yang menjadi dasar gerakan dan pemikiran mereka :

$$
\text { ومن لم يحكم بما أنزل الشه فأولئك هم الكافرون }
$$

Artinya : "Dan barangsiapa tidak memutuskan (perkara) menurut apa yang diturunkan Allah, maka mereka itu orang-orang kafir. ${ }^{8} "$

Dan ayat :

ان الحكم/لاله

Artinya : "Keputusan (hukum) hanyalah milik Allah semata9."

Ayat ini yang menjadi dasar pemikiran dan keputusan mereka menolak opsi arbitrase atau tahkim karena menurut pandangan golongan ini perundingan dan menunjuk juru runding (hakam) dalam peperangan antara Sayyidina Ali dan Muawiyah adalah tidak tepat dan tidak sesuai dengan apa yang diperintahkan al-Qur'an, konsekuensi dari interpretasi mereka terhadap ayat ini, maka yang tidak berhukum dengan hukum Allah baik Ali maupun Muawiyah dihukumi sebagai kafir keluar dari agama islam dan tidak ada kewajiban lagi mengakui mereka sebagai ulil amri yang sah bahkan wajib untuk diperangi. Berangkat dari penafsiran yang rigid dan

${ }^{8}$ Qs. Al-Maidah : 44

${ }^{9}$ Qs. Yusuf : 40 
emosional ini, kemudian mereka banyak menakwil ayat-ayat alQur'an sesuai dengan kecenderungan dan kepentingan politik mereka, beberapa ayat al-Qur'an yang ditakwil, seperti pada ayat :

$$
\text { ومن الناس من يعجبك قوله في الحياة الدنيا ويشهد الله على ما في قلبه وهو ألد الخصام }
$$

Artinya : "Dan diantara manusia ada yang pembicaraannya tentang kehidupan dunia mengagumkan engkau (Muhammad), dan dia bersaksi kepada Allah mengenai isi hatinya, padahal dia adalah penentang yang paling keras $^{10} . "$

Ayat ini mereka takwil bahwa manusia yang dimaksud dalam ayat ini adalah Sayyidina Ali bin Abi Thalib, dengan ayat ini juga mereka menghukumi Sayyidina Ali sebagai seorang kafir ${ }^{11}$.

Pada ayat yang lain dengan motif yang sama mereka berusaha meyakinkan kelompoknya dengan menginterpretasi Kalam Allah dengan interpretasi atau takwil yang bersebrangan dengan kaidah umum takwil, seperti pembelaan mereka kepada Abdurrahman bin Muljam yang dalam sejarahnya dialah sosok yang membunuh Sayyidina Ali ketika melaksanakan sholat di kota kufah irak $^{12}$, dengan ayat :

$$
\text { ومن الناس من يشري نفساه ابتغاء مرضاة الله والله رءوف بالعباد }
$$

${ }^{10}$ Qs. Al-Baqarah : 204

${ }^{11} \mathrm{Al}-$ Qalhati, Al-Kasyf wal Bayan (Tunisia : Tunisia University Press, 1974) Sub Bahasan : kekhalifahan Utsman dan Ali.

${ }^{12}$ Ibid 
Artinya : "Dan diantara manusia ada orang yang mengorbankan dirinya untuk mencari keridhaan Allah. Dan Allah maha penyantun kepada hamba-hambanya ${ }^{13}$."

Takwil-takwil mereka terhadap ayat-ayat al-qur'an ini sedikit tidak menambah kerancuan mereka dalam memahami ajaran islam yang memiliki karakter yang moderat, sehingga berakibat kepada pemahaman yang salah terhadap ayat-ayat atau perintah Allah yang lain.

\section{E. Konsekuensi Lain}

Berangkat dari pemahaman yang tekstual dan didorong kecenderungan politik, kelompok ini akhirnya jatuh kepada pemahaman takfiri sehingga semua sahabat termasuk Sayyidina Utsman, yang terlibat dan menurut mereka setuju dengan arbitrase atau tahkim pasca perang shiffin dan didahului dengan perang jamal dihukumi sebagai orang-orang kafir yang jika menjadi pemimpin tidak wajib dipatuhi bahkan harus di perangi, faktor ini kemudian yang mendorong Abdurrahman bin Muljam yang terkenal sebagai figur yang shaleh dan rajin beribadah membunuh sahabat sekaligus menantu rasulullah, karena menurut mereka barangsiapa yang tidak berhukum menggunakan hukum Allah sesuai dengan ayat alQur'an secara jelas dan gamblang disebut sebagai orang-orang yang keluar dari agama islam.

${ }^{13}$ Qs. Al-Baqarah : 207 
Bahkan menurut mereka, pelaku dosa besar jika tidak bertaubat maka juga jatuh kepada kekafiran dan selama-lamanya berada didalam neraka, karena seseorang itu hanya dalam dua keadaan yaitu kalau bukan mukmin maka dia seorang kafir, maka orang yang fasik atau mencampur adukkan antara keimanan dan dosa besar sudah tentu dengan perspektif hitam putih masuk kedalam kekafiran $^{14}$.

Dengan perspektif yang kaku ini kemudian mereka mengkafirkan banyak kaum muslimin dan menimbulkan perpecahan dalam umat. Pemahaman yang tekstualis ini turut berimplikasi pada penerimaan mereka terhadap hadits-hadits rasulullah, sehingga setiap hadits yang tidak sesuai dengan pemahaman teks ayat al-qur'an harus ditolak dan tidak dilaksanakan ${ }^{15}$, tentu dengan pemahaman semacam ini banyak hadits rasulullah yang akan di tolak sebagai dasar hukum.

Oleh karena itu, selain tentang kafir dan mukmin, implikasi dari metode interpretasi mereka juga terkait dengan persoalan nubuwwat yang jamak diketahui bahwa setiap nabi atau rasul wajib memiliki mukjizat sebagai tanda kebenaran apa yang disampaikan dan bantahan terhadap pengingkaran bagi kaum yang mengingkarinya, tapi dalam pandangan kaum ini mukjizat bukan sebagai sebuah syarat yang harus di miliki oleh seorang nabi ${ }^{16}$. Demikian

${ }_{14}^{14}$ Salim bin Hamd Al-Harisy, Al-Uqud Al-Fiddiyyah Fi Ushulil Ibadiyah (oman : Kementerian Warisan Budaya Nasional, 1983) hal. 228-290

${ }^{15}$ Muhammad Husain Az-Zahabi, Al-Tafsir wa Al-Mufassirun (Wahbah Press, 2000) hal. $301 / 2$

${ }^{16}$ Ibid 
juga bolehnya para nabi sebelum diutus dari golongan pelaku maksiat, kefasikan bahkan kekufuran dan demikian halnya para nabi boleh melakukan kekufuran atau jatuh kepada dosa-dosa kecil ${ }^{17}$, pandangan-pandangan semacam ini tentu sangat berisiko karena akan memunculkan keragu-raguan kepada pribadi nabi yang akibatnya keraguan terhadap ajaran dan seruan yang disampaikan kepada umatnya.

\section{F. Analogi Neo-Khawarij}

Khawarij sebagai sebuah mazhab teologis dan yurisprudensi bisa disebut sudah tidak berkembang lagi seperti masa-masa awal munculnya, tapi Khawarij sebagai spirit dan keyakinan banyak pihak berpendapat tetap eksis dan menjamur sampai saat ini yang kemudian disebut sebagai Neo Khawarij dengan berbagai macam variasinya yang titik temunya ada pada pemahaman takfiri kepada umat islam sendiri yang notebenenya konsisten dalam menjalankan ritual-ritual keagamaannya. Pemahaman takfiri ini kemudian melahirkan radikalisme dengan segenap konsekuensinya dan jika di lihat dengan lebih detail persoalan takfiri sangat erat kaitannya dengan lahirnya radikalisme itu sendiri.

Beberapa sebabnya adalah radikalisme dan pemikiran takfiri sama-sama melihat persoalan-persoalan yang sifatnya sekunder sebagai sesuatu yang primer dan absolut, seperti gerakan khawarij yang melihat persoalan tahkim atau arbitrase sebagai persoalan

${ }^{17}$ Ibid 
mendasar agama yang bisa mengeluarkan seseorang dari akar keimanannya, sama halnya dengan sejarah gerakan-gerakan politik radikal di eropa, sebagai contoh gerakan politik komunis yang terinspirasi dari radikalisme pemikiran karl marx yang serba monolitik dan absolut.

Sebab lain yang kelihatan mencolok adalah, gerakan neo khawarij atau takfiri dan gerakan radikalisme cenderung memilih jalan-jalan kekerasan dalam melakukan perubahan sosial dan politik daripada opsi rekonsiliasi damai bahkan menjurus kepada menghalalkan darah kaum muslimin sendiri lebih-lebih non muslim.

Seperti yang banyak terjadi di berbagai belahan dunia dengan bermacam-macam organisasinya melakukan serangkaian aksi penyerangan mengakibatkan jatuhnya banyak korban meninggal mulai dari anak-anak, perempuan dan orang tua jompo yang dalam melakukan aksinya kelompok-kelompok ini termotivasi dari pandangan mereka yang menganggap persoalan bernegara sebagai bagian dari prinsip-prinsip agama yang harus ditegakkan dengan senjata dan darah seperti rukun islam yang lima yaitu kesaksian ketuhanan Allah yang satu berikut kenabian dan kerasulan $\mathrm{Mu}-$ hammad, mendirikan shalat lima waktu, membayar zakat, melaksanakan puasa pada bulan ramadhan, dan melaksanakan haji. Masih menurut mereka ketika sebuah negara tidak melaksanakan hukum-hukum agama secara kaffah atau komperehensif, maka negara dan pemerintahannya disebut sebagai thagut yang wajib di- 
perangi dan tidak ada kewajiban untuk taat dan tunduk kepadanya dan menurut sebagian kaum muslimin terinspirasi dari pandangan Sayyid Qutb dalam tafsirnya Fi Zhilalil Qur'an.

Gerakan radikal mereka yang tidak mau dan tidak bisa membedakan antara persoalan prinsip dan sekunder diperkeruh dengan pandangan ekstrem kebolehan mengorbankan jiwa manusia dalam aksinya menambah kekhawatiran terhadap gerakan Neo Khawarij ini, pandangan terakhir tersebut muncul dari metode tafsir khawarij masa lalu yang mengambil makna ayat secara zhahirnya tanpa melakukan komparasi dan kodifikasi dengan ayat-ayat yang serupa, dengan tafsir ini kemudian Neo Khawarij melakukan aksinya sekaligus sebagai justifikasi atas apa yang mereka lakukan, sehingga kelompok ini merasa percaya diri dan tidak merasa bersalah atas akibat aksi ekstrem mereka itu.

Eksistensi dan pemahaman kelompok radikal tersebut sampai saat ini masih saja ada bahkan terus bervariasi menjadi berbagai macam kelompok, yang notabene disebabkan bukan karena kuatnya argumentasi tapi lebih kepada adanya unsur fanatisme terlihat dari eksklusivisme kelompok dengan penanaman egoisme kolektif bahwa kelompok dan pemahaman mereka saja yang paling benar yang berakibat kepada tertutupnya ruang dialog dan diskusi, sehingga menjadi sulit mengharapkan perubahan paradigma berpikir. Fanatisme menjadi salah satu yang diingatkan nabi dalam haditsnya untuk berusaha sekuat mungkin dihindari, karena fanatisme termasuk nilai-nilai jahiliyah yang bisa merusak 
keluhuran budi pekerti dan kemajuan masyarakat karena pada hakikatnya fanatisme itu menolak kebenaran, bahkan banyak kalangan berpendapat kemunduran yang disebabkan perpecahan pada masa lalu dan saat ini karena sebagian umat islam tidak menggubris peringatan nabi untuk menjauhi fanatisme.

\section{G. Radikalisme di Indonesia}

Benih radikalisme di indonesia sebetulnya sudah ada sejak berdirinya indonesia sebagai negara bangsa dengan munculnya DI/TII atau Darul Islam/Tentara Islam Indonesia dan NII (Negara Islam Indonesia). Seperti mazhab khawarij kelompok ini muncul dari pemahaman bahwa indonesia dengan pancasila dan UUD 45 belum menerapkan sistem islam yang kaffah, karena itu menjadi kewajiban bagi umat islam untuk mengubah sistem kenegaraan tersebut menjadi sistem yang islami yang sesuai dengan perintah Al-Qur'an maupun Hadits Rasulullah SAW. Sistem islam yang kaffah bagi mereka adalah sistem yang ideal untuk negara, dengan dijadikannya Al-Qur'an dan Hadits sebagai dasar dan konstitusi. Konsekuensi dari tidak dilaksanakannya hal tersebut adalah kewajiban bagi warga negaranya untuk merubah sistem tersebut walaupun dengan cara atau tindakan yang anarkis.

Dalam pandangan mereka, sistem islam kaffah adalah sistem yang mengatur semua aspek kehidupan masyarakat baik ekonomi, politik, sosial, hukum dan lain-lain yang bersumber dari hukumhukum yang ada dalam Al-Qur'an dan Hadits. Pancasila dan UUD 45 menurut mereka, tidak sesuai dengan syariat islam yang ber- 
sumber dari Al-Qur'an maupun hadits. Gerakan ini pada masa awal kemerdekaan mengalami perkembangan yang luas dan menimbulkan banyak korban walaupun berhasil diredam pergerakannya tapi pemikiran-pemikiran mereka tetap berlanjut bahkan sampai sekarang menjadi berbagai macam kelompok dan komunitas dan jika ditilik lebih jauh gerakan ini muncul sama seperti pendahulunya lebih disebabkan ketidakpuasan secara politik yang kemudian jatuh pada politisasi agama dan syariat.

Tapi beruntungnya mazhab semacam ini tidak mendapat tempat di hati masyarakat, tidak seperti di tempat atau negara lain hanya sebagian kecil saja masyarakat yang tertarik dengan pemahaman mereka, faktor penolakan masyarakat selain yang sifatnya doktrin juga karakter masyarakat nusantara secara umum lebih cenderung menghindari tindakan atau pemahaman yang ekstrem atau anarkis dan lebih menyukai keragaman dan pendekatan persuasif.

\section{H. Tawaran Analisa}

Dalam melihat fenomena isme ini, banyak alasan dan argumentasi untuk menolak pandangan tersebut setidaknya bisa dirangkum dalam tiga perspektif ;

\section{Perspektif Kemanusiaan}

Hak hidup dan memperoleh keamanan merupakan sisi kemanusiaan yang tidak bisa ditolak oleh siapapun, selama seseorang menggunakan akalnya maka menghilangkan atau mengorbankan 
jiwa manusia adalah perbuatan yang tidak manusiawi tidak bisa diterima oleh manusia, bangsa atau agama apapun. Dan karena itu, dalam sejarah panjang hidup manusia ketika satu nyawa hilang maka akan berdampak kepada eskalasi konflik yang lebih besar lgi, untuk menghindari itu berbagai macam aturan dan undangundang diterbitkan mulai dari hukuman yang setimpal hukuman mati bagi pelaku pembunuhan, penjara seumur hidup atau berbagai macam bentuk hukuman lainnya yang notebenenya untuk menghindari konflik yang berkepanjangan.

Untuk merespon kekhawatiran semacam itu, tepatnya setelah perang dunia kedua yang mengakibatkan banyaknya korban maka dunia internasional melalui Majelis Umum PBB, mendeklarasikan sebuah pernyataan umum yang kemudian disebut Universal Declaration of Human Rights atau Pernyataan Umum tentang Hak Asasi Manusia yang mengatur hak-hak asasi manusia yang harus diakui dan tidak boleh dilanggar ${ }^{18}$, dari sekian hak-hak yang diatur itu, yang pertama disebutkan adalah hak hidup dan keamanan ${ }^{19}$, tentu ini menunjukkan begitu pentingnya jaminan terhadap hak hidup dan keamanan baik keamanan diri, keamanan lingkungan ataupun keamanan tempat tinggal.

Demikian halnya jika dilihat dari sisi maju mundurnya masyarakat yang melahirkan identitas peradaban, pandangan ekstrem semacam ini harus ditinggalkan karena tidak masuk akal

${ }^{18}$ Yahya ahmad zein, S.H, M.H, Problematika Hak Asasi Manusia (HAM) (Yogyakarta: Liberty Yogyakarta, 2012) hal. 168.

${ }^{19}$ Ibid 
identitas kemajuan akan tercapai, jika radikalisme tersebut masih eksis ditengah masyarakat, logika sederhananya membangun membutuhkan proses yang tidak cepat tapi merusak dan menghancurkan hanya butuh waktu sesaat dan untuk membangun lagi membutuhkan waktu yang panjang, karena itu jika bercermin dari sejarah perabadan-peradaban besar didunia pandangan radikal seperti pandangan Neo Khawarij tersebut sudah lebih dulu dihilangkan dari pikiran masyarakatnya.

\section{Teks Agama}

Sedari dulu eksistensi pemikiran Khawarij dengan karakter yang radikal sudah banyak ditolak oleh kaum muslimin sendiri, dimulai dari ahli tafsir sahabat rasulullah Ibnu Abbas yang berusaha berdialog dengan kaum tersebut sampai masa-masa selanjutnya, mayoritas ulama juga secara bersama-bersama berusaha menangkal pemikiran-pemikiran mereka, karena pandangan mereka tidak sesuai dengan kaidah-kaidah dan metode tafsir yang benar terhadap alqur'an dan hadits rasulullah seperti doktrin kekafiran orang yang mengikuti proses tahkim atau arbitrase zaman Sayyidina Ali, kekufuran para sahabat Rasulullah termasuk Ali, Utsman, dan lainnya, kekufuran orang yang berbuat dosa besar, tentu tidak sesuai dengan pemahaman yang benar dan disepakati oleh seluruh ulama dan kaum muslimin, bahwa selama seseorang tidak mengingkari dan melaksanakan substansi-substansi agama seperti rukun islam maupun rukun iman maka, tidak boleh serta 
merta dihukumi sebagai orang yang keluar dari doktrin dan kepercayaan agama $^{20}$.

Sebagaimana pandangan kaum muslimin berdasarkan hadits rasulullah, dalam sebuah sabdanya rasululullah mengabarkan bahwa Abu Bakar, Umar, Utsman, Ali, Thalhah, Zubair, Abdurrahman bin Auf, Sa'ad, Sa'id, Abu Ubaidah bin Jarrah termasuk penghuni syurga ${ }^{21}$ demikian juga para sahabatnya yang lain.

Terlebih pandangan mereka yang membolehkan membunuh kaum muslimin baik karena berbeda doktrin ataupun karena efek dari aksi-aksi mereka seperti yang diyakini oleh kelompokkelompok Neo Khawarij saat sekarang ini, tentu jauh dari tuntunan rasululullah, yang dalam peperanganpun tidak boleh membunuh wanita, anak-anak ${ }^{22}$ ataupun orangtua jompo ${ }^{23}$ apalagi sampai mengorbankan orang yang tidak bersalah ${ }^{24}$, bahkan orang kafirpun selama tidak memerangi kaum muslimin tidak boleh diperangi dan diambil hak hidupnya ${ }^{25}$, nilai-nilai moral yang tetap dipegang tersebut sekali lagi membuktikan islam dalam situasi apapun tetap menjunjung tinggi integritas dan akhlak dan juga membuktikan ajaran yang dibawa Rasulullah adalah seruan kepada perdamaian dan harmoni jauh dari segala hal yang di tuduhkan sebagai ajaran radikal dan antipati kepada kemanusiaan.

${ }^{20}$ Ibnu Hajar Al-Asqolani, Fath Al-Bari Syarh Shahihil Bukhari (Kairo : Al-Salafiyah Publisher, 2015) hal. 202/12

${ }^{21} \mathrm{Al}$-Turmuzi, Sunan Al-Turmuzi, (Beirut, Dar Ihya' Al-Turats, t.th), 3747.

${ }^{22}$ Al-Imam Muslim, Shahih Muslim (Kairo, Dar Al-Thayyibah, 2006) No. 1744

${ }^{23}$ Abu Dawud, Sunan Abi Dawud (Kairo, Dar Al-Risalah Al-'Alamiah, 2009) 2614

${ }^{24}$ Qs. Al-Maidah : 32

${ }^{25}$ Al-Imam Al-Bukhari, Shahih Al-Bukhari (Beirut, Dar Ibnu Katsir, 2002) 3166 


\section{Negara}

Selain perspektif agama dan kemanusiaan, pandangan dan doktrin kelompok ini juga tidak sesuai dengan konsep kenegaraan kita yang berdasar pada pancasila dan undang-undang dasar 1945, pancasila yang merupakan dasar negara mengamanatkan lima sila atau prinsip yang secara umum memberikan ruang bagi seluruh rakyat dan kelompok masyarakat berkonstribusi secara bersamasama dalam membangun negeri tanpa berpihak kepada satu golongan saja, demikian juga membuka ruang yang sama dalam menjamin pemenuhan hak-hak politik, sosial ataupun agama dengan dibukanya kebebasan melaksanakan perintah dan ajaran agama tanpa diskriminasi dan pembedaan sedikitpun seperti yang tertuang dalam sila pertama pancasila ketuhanan yang maha esa.

Berangkat dari pemahaman sila pertama ini, setiap warga negara mempunyai kedudukan yang sama dalam menjalankan agama dan keyakinannya dalam bingkai negara kesatuan republik indonesia (NKRI), karena itu tidak dikenal istilah warga negara kedua atau pertama, dengan realitas satu keyakinan atau kelompok agama tertentu lebih mendominasi praktik keagamaannya dari pada yang lain, untuk menjamin hal tersebut maka indonesia berdiri dengan satu sistem yang disebut dengan negara pancasila, bukan negara agama yang mendasarkan sistem kenegaraan dan perundang-undangannya dengan keyakinan tertentu, juga bukan negara yang tidak berketuhanan atau melawan nilai-nilai keagamaan yang 
menjadi fitrah kemanusiaan dalam komitmen menjaga persatuan dan kebhinnekaan sebagai satu bangsa dan tanah air.

Demikian halnya dalam UUD 1945 yang menjadi konstitusi negara, dalam pembukaan atau preambulenya ditegaskan bahwa kemerdekaan indonesia yang merdeka, bersatu, berdaulat, adil dan makmur terbentuk dalam suatu susunan negara republik indonesia yang berkedaulatan rakyat dengan berdasar kepada lima prinsip dasar negara ${ }^{26}$. Dalam konstitusi ini dijelaskan dengan gamblang dasar dan prinsip bernegara yang meniscayakan persatuan dalam keanekaragaman agama, kultur dan suku. Karena sejarah kemerdekaan diraih bukan oleh satu kelompok atau golongan, tapi melibatkan semua pihak lintas agama dan golongan.

Hal ini kemudian yang disadari oleh para founding fathers negeri, sehingga setelah melalui proses dan musyawarah yang alot yang kala itu sebagian kelompok umat islam bersikukuh ingin memasukkan tujuh kata yaitu "dengan kewajiban menjalankan syariat islam bagi pemeluk-pemeluknya" dalam dasar negara pancasila yang tertuang didalam pembukaan UUD 1945, tapi dengan pertimbangan yang matang dan dengan kesadaran semua kelompok dan golongan masyarakat, pada akhirnya tujuh kata itu dihapuskan dan jika tujuh kata itu tetap ada dalam UUD 1945 sebagai konstitusi negara tentu akan berimplikasi luas. Konsekuensi dari keberadaan tujuh kata tersebut adalah, terbentuknya negara agama dan bisa t th) hal 5

${ }^{26}$ Undang-Undang Dasar 1945-Amandemen I,II,III,IV (Jakarta, Palito media, 
berakibat pada pecahnya persatuan bangsa yang sebelum kemerdekaan dan dalam proses mencapai kemerdekaan merupakan masyarakat heterogen, tentu tidak mudah mempersatukannya apalagi pada masa awal-awal kemerdekaan, fakta tersebut disadari oleh kaum muslimin sebagai kelompok mayoritas dan pada akhirnya dengan legowo menerima penghapusan tujuh kata tersebut dari konstitusi negara. Fakta sejarah ini oleh banyak kalangan disebut sebagai hadiah terbesar umat islam kepada negeri ini sekaligus menampilkan wajah islam yang sesungguhnya yang bercirikan moderatisme.

Isi dan amanah pancasila sebagai dasar negara dan UUD 1945 sebagai konstitusi kenegaraan pada substansinya sesuai dengan piagam madinah atau madinah charter yang dicontohkan rasulullah pada masa kenabian.

Setelah 13 tahun di kota mekkah dengan beberapa sebab Rasulullah melakukan hijrah ke kota Madinah yang sebelumnya bernama Yatsrib, sebelum hijrah kondisi kota tersebut penduduknya terdiri dari berbagai macam kelompok, agama dan golongan. Dari sisi keyakinan setidaknya ada tiga agama yang berkembang selain islam yaitu yahudi, kristen dan paganisme atau penyembah berhala, pada saat itu juga terjadi perpecahan di kalangan masyarakat, bahkan peperangan antar kelompok dan go- 
longan menjadi satu realita masyarakat kota itu ${ }^{27}$ apalagi penduduk madinah tidak mengenal dominasi kekuasaan tertentu yang bisa menyatukan masyarakatnya, karena fakta tersebut setiap kelompok atau kabilah saling serang antar satu dengan yang lainnya mempertahankan eksistensi masing-masing pada akhirnya membuat ketidakstabilan bukan hanya dalam politik tapi juga sosial bahkan mengarah kepada aktivitas ekonomi masyarakat yang saling merugikan karena ketiadaan keteraturan di kota tersebut.

Dalam kondisi yang serba carut-marut tersebut tentu yang menjadi hakim adalah yang kuat siapa yang kuat ialah yang berkuasa, situasi yang demikian seperti berada dalam hukum rimba tidak adanya aturan atau undang-undang yang bisa mengatur masyarakat. Fonemena semacam ini bukan hanya ada di kota Yatsrib tapi menjadi pola umum masyarakat dibelahan dunia lain pada masa itu, pemerintahan hanya sebatas kepala suku dan setiap suku hanya mementingkan urusannya masing-masing sementara bidang ekonomi salah satu aspek paling penting dalam sebuah masyarakat banyak dikuasai oleh orang-orang yahudi ${ }^{28}$ yang menimbulkan kecemburuan dari kelompok-kelompok lain. Dalam kondisi yang serba tidak teratur terdapat beberapa penduduk madinah mulai mendengar kabar risalah kenabian Nabi kemudian datang ke

${ }^{27}$ Prof. Dr. H. Ahmad Sukardja, S.H., M.A. Piagam Madinah dan UndangUndang Dasar NRI 1945 Kajian Perbandingan tentang Dasar Hidup Bersama dalam Masyarakat yang Majemuk (Jakarta Timur, Sinar Grafika 2012) hal 52

${ }^{28}$ Prof. Dr. H. Ahmad Sukardja, S.H., M.A. Piagam Madinah dan UndangUndang Dasar NRI 1945 Kajian Perbandingan tentang Dasar Hidup Bersama dalam Masyarakat yang Majemuk (Jakarta Timur, Sinar Grafika 2012) hal 54 
kota mekkah menemui Nabi dan menyatakan keislamannya, salah satunya orang-orang dari suku khazraj ${ }^{29}$ sejak saat itu kabar dakwah nabi semakin meluas di kalangan penduduk madinah.

Sesampainya di Madinah dan mendapati masyarakat yang multisuku, agama dan perpecahan di masyarakat maka Rasulullah yang sudah memperoleh kepercayaan penduduk madinah mengumpulkan mereka dan mengajak berunding untuk mensepakati sebuah perjanjian yang disebut sebagai Piagam Madinah ${ }^{30}$ perjanjian yang akan mengatur kehidupan masyarakat dalam semua bidang baik politik, ekonomi, sosial maupun yang lainnya ${ }^{31}$. Setelah melalui proses musyawarah yang cukup alot yang melibatkan semua suku,agama dan kelompok di Madinah maka dengan bulat piagam tersebut disepakati dan diterima semua pihak, pada selanjutnya kesepakatan tersebut menjadi konstitusi negara madinah yang banyak kalangan menyebut bahwa piagam madinah atau madinah charter menjadi konstitusi tertulis pertama dalam sejarah kenegaraan yang pernah ada.

Perjanjian ini berisi 47 pasal, 23 pasal memuat tentang hubungan antara umat islam dan 24 pasal lainnya tentang hubungan

${ }^{29}$ Ibn Hisyam, al-Sirah an-Nabawiyah, Tahkik: Umar Abdussalam Tadmuri (Beirut, Dar al-Kitab al-Arabi 1990) hal 428 jilid 1

${ }^{30}$ Prof. Dr. H. Ahmad Sukardja, S.H., M.A. Piagam Madinah dan UndangUndang Dasar NRI 1945 Kajian Perbandingan tentang Dasar Hidup Bersama dalam Masyarakat yang Majemuk (Jakarta Timur, Sinar Grafika 2012) hal 1-2

${ }^{31}$ Prof. Dr. H. Ahmad Sukardja, S.H., M.A. Piagam Madinah dan UndangUndang Dasar NRI 1945 Kajian Perbandingan tentang Dasar Hidup Bersama dalam Masyarakat yang Majemuk (Jakarta Timur, Sinar Grafika 2012) hal 1-2 
umat islam dengan umat lain ${ }^{32}$, artinya semua kepentingan masyarakat lintas agama, suku dan kelompok terakomodir pada perjanjian ini apalagi dalam pasal satu termuat bahwa penduduk madinah adalah umat yang satu, hal ini menunjukkan pasal-pasal selanjutnya semuanya dalam semangat persatuan tanpa ada dominasi antara satu dengan yang lainnya atau merugikan pihak lain. Secara umum, perjanjian ini sebagai perlindungan hak dan kewajiban seluruh masyarakat dalam bidang agama, politik, pertahanan keamanan, sosial, ekonomi dan lain-lain untuk mewujudkan suatu masyarakat yang baladan amina aman dan sejahtera. Kandungan konstitusi ini dalam rangka membangun masyarakat madani atau civil society, sebuah masyarakat yang berperadaban ditandai dengan sifat keterbukaan, toleransi, kebebasan, kecintaan kepada ilmu pengetahuan yang diikat oleh satu tatanan nilai dan aturan bersama. Kandungan undang-undang semacam ini belum ada sebelumnya yang secara detail dan terperinci mengatur semua aspek baik dalam tatanan masyarakat, dalam hubungan masyarakat dengan negara bahkan dalam pergaulan internasional negara 33 .

Jika melihat sejarah dan kandungan piagam madinah, bisa disimpulkan sejarah dan substansi dari UUD 1945 sebagai konsti-

${ }^{32}$ Prof. Dr. H. Ahmad Sukardja, S.H., M.A. Piagam Madinah dan UndangUndang Dasar NRI 1945 Kajian Perbandingan tentang Dasar Hidup Bersama dalam Masyarakat yang Majemuk (Jakarta Timur, Sinar Grafika 2012) hal 79

${ }_{33}$ Prof. Dr. H. Ahmad Sukardja, S.H., M.A. Piagam Madinah dan UndangUndang Dasar NRI 1945 Kajian Perbandingan tentang Dasar Hidup Bersama dalam Masyarakat yang Majemuk (Jakarta Timur, Sinar Grafika 2012) hal 81-88 
tusi negara kita terdapat kesamaan dan sesuai dengan apa yang dicontohkan Nabi melalui piagam madinah tersebut. Khususnya, heterogenitas penduduknya demikian halnya dengan kandungannya prinsip-prinsip kesatuan bangsa, kebebasan beragama, perlindungan terhadap hak dan kewajiban segenap masyarakat. Oleh karena itu, menganggap konstitusi negara tidak sesuai dengan prinsip-prinsip doktrin keagamaan tentu hal yang keliru, seperti anggapan sebagian kelompok umat islam khususnya kalangan islam garis keras dan dengan alasan tersebut mereka menjustifikasi tindakan-tindakan anarkis, yang sesungguhnya tidak sesuai dengan ajaran islam itu sendiri. Dengan demikian indonesia dengan pancasila dan UUD 1945, sah sebagai negara dari sisi agama. Maka menjalankan semua aturan dan undang-undang yang ada adalah bagian dari perintah Allah untuk mentaati pemimpin.

\section{Penutup}

Jika melihat karakter islam yang dibawa Rasulullah selama dua puluh tiga tahun di kota Mekkah dan Madinah, maka tidak terlihat sama sekali indikasi atau kecenderungan yang menunjukkan adanya radikalisme dalam gerakan dakwah beliau seperti banyak dituduhkan, justru sebaliknya ajaran yang dikedepankan lebih kepada nilai-nilai moderasi dan toleransi baik dalam ritual agama islam itu sendiri maupun bidang-bidang yang lain seperti sosial, politik bahkan ekonomi. Akan tetapi hal yang tak terbantahkan juga, jika islam dikaitkan dengan gerakan-gerakan radikalisme, seperti sejarah Khawarij yang kemudian bermetamorfosis menjadi ke- 
lompok-kelompok garis keras atau biasa disebut Neo Khawarij, tetapi seperti banyak dijelaskan oleh para cendekiawan muslim gerakan-gerakan radikal tersebut hanya bentuk interpretasi mereka terhadap al-qur'an dan hadits yang sifatnya subjektif dan didasari kecenderungan politik mereka baik sejak munculnya sampai saat ini. Oleh karena itu, mengaitkan ajaran islam an sich dengan radikalisme tentu keliru, tapi jika radikalisme tersebut dipahami sebagai interpretasi seseorang atau kelompok maka banyak kalangan termasuk para ulama dan cendekiawan muslim mengakui dan membenarkannya.

\section{Daftar Pustaka}

Al-Qur'an

Al-Bukhari, Abu Abdillah, Shahih Al-Bukhari, (Beirut: Dar Ibnu Katsir, 2002)

Al-Qalhati, Al-Kasyf Wal Bayan, (Tunisia : Tunisia University Press, 1974) Sub Bahasan :Kekhalifahan Utsman dan Ali.

Al-Harisy, Salim bin Hamd, Al-Uqud Al-Fiddiyyah Fi Ushulil Ibadiyah, (oman : Kementerian Warisan Budaya Nasional, 1983)

Az-Zahabi, Muhammad Husain, Al-Tafsir Wa Al-Mufassirun, (Wahbah Press, 2000)

Al-Asqolani, Ibn Hajar, Fath Al-Bari Syarh Shahihil Bukhari, (Kairo : Al-Salafiyah Publisher, 2015) 
Al-Turmuzi, Sunan Al-Turmuzi, (Beirut, Dar Ihya' Al-Turats, t.th)

Dawud, Abu, Sunan Abi Dawud, (Kairo, Dar Al-Risalah Al-'Alamiah, 2009)

Hisyam, Ibn, Al-Sirah An-Nabawiyah, Tahkik: Umar Abdussalam Tadmuri (Beirut, Dar al-Kitab al-Arabi 1990)

Hasan, Masudul, History of Islam, (India: Adam Publishers and Distributors, 1995)

Muslim, Abu Al-Husain, Shahih Muslim, (Kairo, Dar Al-Thayyibah, 2006)

Montogomery Waat, William, The Formative Period of Islamic Thought, (Edinburgh: Edinburgh University Press, 1973)

Sukardja, Ahmad, Piagam Madinah dan Undang-Undang Dasar NRI 1945 Kajian Perbandingan tentang Dasar Hidup Bersama dalam Masyarakat yang Majemuk, (Jakarta Timur, Sinar Grafika 2012)

Undang-Undang Dasar 1945-Amandemen I,II,III,IV, (Jakarta, Palito media, $\mathrm{t}$ th)

Zein,Yahya Ahmad, Problematika Hak Asasi Manusia (HAM), (Yogyakarta, Liberty Yogyakarta, 2012) 